\title{
South Asian contributions to animal domestication and pastoralism
}

\section{Citation}

Patel, Ajita K., and Richard H. Meadow. "South Asian Contributions to Animal Domestication and Pastoralism: Bones, Genes, and Archaeology." In The Oxford Handbook of Zooarchaeology, 280-303. Oxford, UK: Oxford University Press, 2017.

\section{Published Version}

doi:10.1093/oxfordhb/9780199686476.013.19

\section{Permanent link}

http://nrs.harvard.edu/urn-3:HUL.InstRepos:37308546

\section{Terms of Use}

This article was downloaded from Harvard University's DASH repository, and is made available under the terms and conditions applicable to Other Posted Material, as set forth at http:// nrs.harvard.edu/urn-3:HUL.InstRepos:dash.current.terms-of-use\#LAA

\section{Share Your Story}

The Harvard community has made this article openly available.

Please share how this access benefits you. Submit a story.

\section{Accessibility}




\title{
THE OXFORD HANDBOOK OF
}

\section{ZOOARCHAEOLOGY}

\author{
Edited by \\ UMBERTO ALBARELLA \\ with \\ MAURO RIZZETTO, HANNAH RUSS, \\ KIM VICKERS, \\ and \\ SARAH VINER-DANIELS
}




\section{OXFORD}

\section{UNIVERSITY PRESS}

Great Clarendon Street, Oxford, ox2 6DP, United Kingdom

Oxford University Press is a department of the University of Oxford. It furthers the University's objective of excellence in research, scholarship, and education by publishing worldwide. Oxford is a registered trade mark of

Oxford University Press in the UK and in certain other countries

$$
\text { (C) Oxford University Press } 2017
$$

The moral rights of the authors have been asserted

$$
\begin{gathered}
\text { First Edition published in } 2017 \\
\text { Impression: } 1
\end{gathered}
$$

All rights reserved. No part of this publication may be reproduced, stored in a retrieval system, or transmitted, in any form or by any means, without the prior permission in writing of Oxford University Press, or as expressly permitted by law, by licence or under terms agreed with the appropriate reprographics rights organization. Enquiries concerning reproduction outside the scope of the above should be sent to the Rights Department, Oxford University Press, at the

$$
\text { address above }
$$

You must not circulate this work in any other form and you must impose this same condition on any acquirer

Published in the United States of America by Oxford University Press 198 Madison Avenue, New York, NY 10016, United States of America

British Library Cataloguing in Publication Data

Data available

Library of Congress Control Number: Yet to come

$$
\text { ISBN 978-0-19-968647-6 }
$$

Printed and bound in Great Britain by Clays Ltd, St Ives plc

Links to third party websites are provided by Oxford in good faith and for information only. Oxford disclaims any responsibility for the materials contained in any third party website referenced in this work. 
Note: this proof has only a single minor capitalization error.

\section{CHAP TER 18}

\section{SOUTH ASIAN CONTRIBUTIONS TO ANIMAL DOMESTICATION AND PASTORALISM \\ bones, genes, and archaeology}

AJITA K. PATEL AND RICHARD H. MEADOW

\section{INTRODUCTION}

South Asia is an amalgam-a masala - of past and present cultural practices and traditions that has been sustained by the subcontinent's paradox of isolation and connection. As a peninsula to the south of the high Himalayas jutting out into the Indian Ocean, access to and from the subcontinent is challenging, with even traditional overland routes in the northwest and northeast presenting their share of obstacles with major river systems, deserts, and rainforests to be crossed. Yet traversed they have been in history and prehistory, with influences from outside reaching deep into the peninsula and those from within spreading west and east by land and eventually by sea and even north through high mountain passes. During the Holocene, the region has seen the episodic and uneven development of animal and plant management, domestication, and agropastoral practices, resulting in a mosaic of commitment to the use of varied domesticated resources.

In this essay, we focus on the northwest, a zone that has provided evidence for two major cultural phenomena, namely, the earliest development of plant and animal husbandry and the first manifestations of urbanism in the subcontinent. The latter phenomenon - the Indus or Harappan civilization-was spread across much of the 
northwest in the second half of the third millennium cal $\mathrm{BC}$, with a subsistence base founded on agro-pastoral developments of the preceding four or five millennia.

Throughout that long period of socio-economic development, there was complex use of the landscape. From at least as early as the eighth millennium cal BC, in steppic and semi-arid areas of North Gujarat, southern Rajasthan, and eastern parts of Sindh, mobile hunter-gatherer communities with microlithic tool technologies often occupied stabilized sand dunes, where they took advantage of the fauna attracted to the water and vegetation in the interdunal depressions. By the early fourth millennium cal BC, mobile pastoralists using ceramics and herding primarily cattle began taking advantage of these same dunes and interdunal depressions, while other Chalcolithic populations began establishing sedentary agro-pastoral communities of various sizes throughout the region where arable land was available. Through this period and even into the Iron Age, there is evidence for groups continuing to use microlithic tool technologies of the kind traditionally associated with hunter-gatherers, while also incorporating domestic animals and plants as well as ceramics and eventually metals into their lifeways.

Farther north and west, settlements are found in areas of the semi-arid Balochistan highlands and along the arid western margins of the Indus plain dating as early as the late eighth millennium cal вс. While there are Upper Palaeolithic assemblages in the area, the immediate antecedents of the early settlements have yet to be found. To the east, available archaeological evidence indicates that significant settled occupation did not occur before the fourth millennium cal BC, by which time agro-pastoral practices that were developed in the highlands and along the alluvial margins had been transferred deep into the riverine zones of the Indus River and its tributaries. When this transfer began to take place, however, remains to be determined. There has been little research into the archaeology of the fifth and sixth millennia cal BC in this area, probably due as much to the focus on the later Indus civilization and its immediate antecedents as to the inherent difficulties of locating small settlements in active riverine zones that also have been further transformed by recent human activity (C. Jarrige et al., 1995; Possehl, 1999).

The transfer of agro-pastoralism into the alluvial zones included notably the crop domesticates wheat and barley and domestic sheep, goat, and cattle. Although these forms tended to dominate, wild plants and animals were widely exploited, with some becoming managed and eventually domesticated including local millets, pulses, sesame, cotton, and rice as well as water buffalo (Meadow, 1996; Patel and Meadow, 1998; Fuller and Madella, 2002).

In the following pages an effort is made to describe some of our current understandings of the domestication and exploitation of goat, sheep, cattle, and water buffalo in northwestern South Asia from the eighth through the third millennium cal BC and the nature of the evidence on which those understandings are based. That evidence derives primarily from archaeological, zooarchaeological, and genetic investigations, 


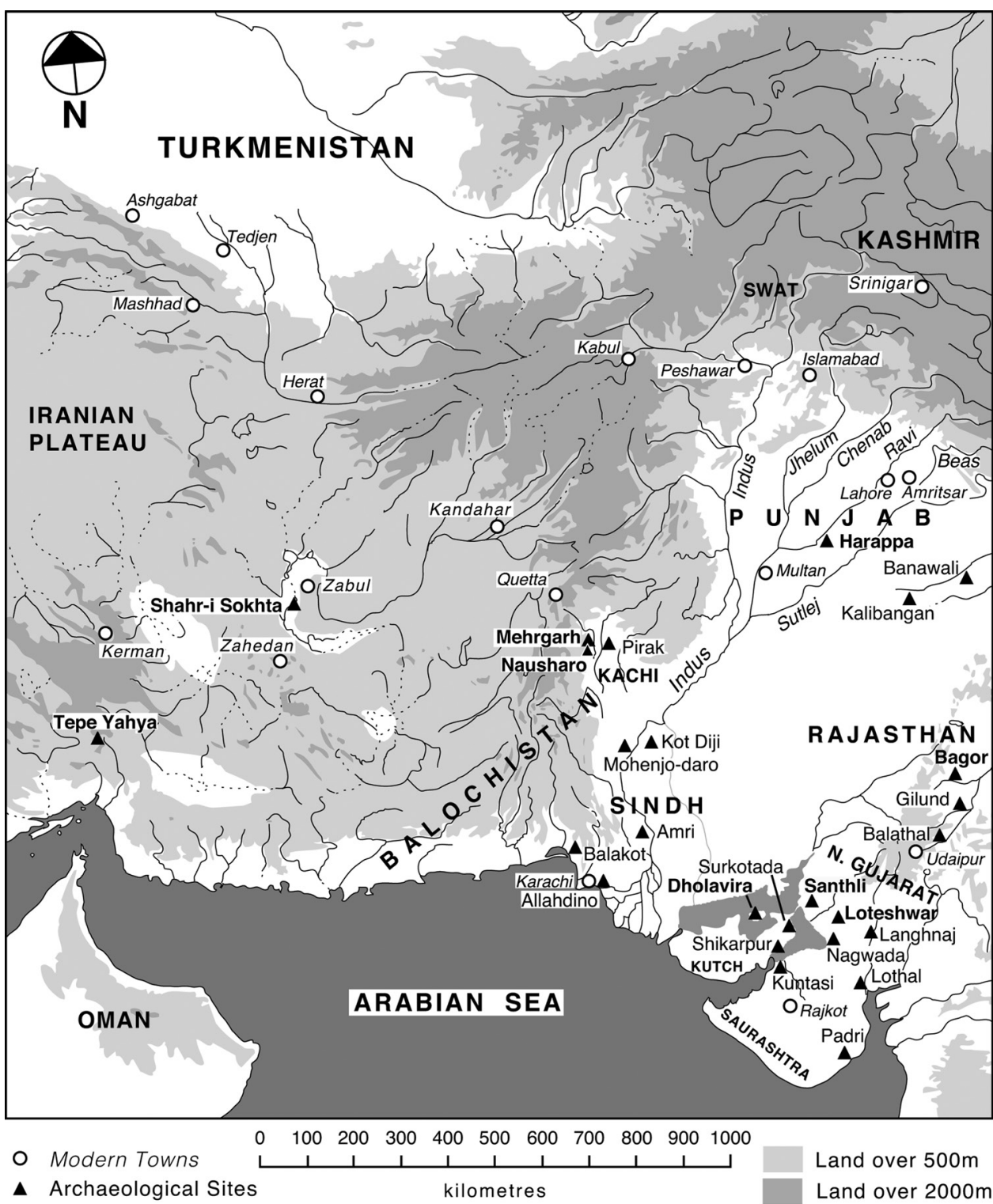

FIGURE 18.1 Map of northwestern South Asia and lands to the west with the approximate locations of key archaeological sites plotted. Names of sites featuring prominently in the text are displayed in bold. Authors' own image.

each of which has its own contributions to make but also limitations, which are discussed as well. A map is provided of northwestern South Asia and areas to the west with the locations of significant archaeological sites including those discussed in the text (Fig. 18.1). 


\section{Wild Ungulates of THE NorthWest}

The indigenous wild fauna of the northwestern South Asia is largely Indo-Malayan in the lowlands of the Indus River system and continuing farther east and south; it is mostly Palearctic through the western and northern highlands and onto the Iranian plateau (Roberts, 1997; Menon, 2009). The taxa most frequently attested in the archaeological record from this region include the wild ungulates listed in Table 18.1 (with the addition of the elephant). Today, many large mammals other than domesticates are scarce and their ranges restricted in response to centuries of human predation and landscape modification. The small bovids blackbuck and chinkara, however, still occur through much of sub-Himalayan India. In Pakistan the blackbuck has been hunted to extinction as has most large game, but the chinkara is still found across Balochistan and onto the eastern Iranian plateau. Wild boar live throughout much of the sub-continent as do the nilgai, chowsingha, sambar, chital, and muntjack. The swamp deer and hog deer today have more restricted distributions than they did in the past, as is also the case for elephant and rhinoceros, which is reflected in the archaeofaunal record. Historically, the onager was widely distributed through the northwest, including in the western highlands, but today it is confined to preserves in Kutch and North Gujarat. Wild goats and sheep of different species are found throughout the western and northern highlands. Those of concern here, the bezoar, urial, and mouflon, are discussed below, as is the wild water buffalo. The wild cattle of South Asia are extinct, known only from the palaeontological and archaeological records.

\section{GOAT AND SHEEP}

The initial domestication of both goat (Capra hircus) and sheep (Ovis aries) is generally thought to have taken place in Southwest Asia. Yet the distributions of their likely wild ancestral forms Capra aegagrus (the bezoar) and Ovis orientalis (the mouflon) today extend across the Iranian plateau and into northwestern South Asia. Thus possibilities may have existed for local management leading to domestication and for cross-breeding between wild and domestic forms.

\section{Goat}

The first managed or domesticated bovid in northwestern South Asia was the goat, evidence for which comes from the earliest levels at the site of Mehrgarh located at the foot of the Bolan Pass in eastern Balochistan. An extensive Aceramic Neolithic occupation (Period I, late eighth into the sixth millennium cal $\mathrm{BC}$ ) is represented by over six metres 
Table 18.1 Wild ungulates (and elephant), the remains of which have been identified from northwestern South Asian archaeological sites prominently mentioned in the text

\begin{tabular}{|c|c|c|}
\hline Taxonomic designation & Common name & From the site(s) of: \\
\hline $\begin{array}{l}\text { Elephas maximus indicus } \\
\text { Cuvier, } 1798\end{array}$ & Indian elephant & Mehrgarh \\
\hline $\begin{array}{l}\text { Rhinoceros unicornis } \\
\text { Linnaeus, } 1758\end{array}$ & Indian rhinoceros & Mehrgarh? \\
\hline $\begin{array}{l}\text { Bos namadicus } \\
\text { Falconer, } 1859\end{array}$ & South Asian wild cattle & Mehrgarh, Loteshwar \\
\hline $\begin{array}{l}\text { Bubalus arnee } \\
\text { Kerr, } 1792\end{array}$ & wild water buffalo & $\begin{array}{l}\text { Mehrgarh, Loteshwar, Santhli, } \\
\text { Bagor?, Dholavira }\end{array}$ \\
\hline $\begin{array}{l}\text { Boselaphus tragocamelus } \\
\text { Pallas, } 1766\end{array}$ & nilgai & $\begin{array}{l}\text { Mehrgarh, Loteshwar, Santhli, } \\
\text { Dholavira? }\end{array}$ \\
\hline $\begin{array}{l}\text { Capra aegagrus } \\
\text { Erxleben, } 1777\end{array}$ & bezoar & Mehrgarh \\
\hline $\begin{array}{l}\text { Ovis orientalis } \\
\text { Gmelin, } 1774\end{array}$ & mouflon & Mehrgarh?, Nausharo? \\
\hline $\begin{array}{l}\text { Ovis vignei } \\
\text { Blyth, } 1841\end{array}$ & urial & Mehrgarh? \\
\hline $\begin{array}{l}\text { Antilope cervicapra } \\
\text { Linnaeus, } 1758\end{array}$ & blackbuck & $\begin{array}{l}\text { Mehrgarh, Loteshwar, Santhli, } \\
\text { Bagor, Dholavira }\end{array}$ \\
\hline $\begin{array}{l}\text { Gazella bennettii } \\
\text { Sykes, } 1831\end{array}$ & Indian gazelle, chinkara & $\begin{array}{l}\text { Mehrgarh, Loteshwar, Santhli, } \\
\text { Bagor, Dholavira }\end{array}$ \\
\hline $\begin{array}{l}\text { Tetracerus quadricornis } \\
\text { de Blainville, } 1816\end{array}$ & chowsingha & $\begin{array}{l}\text { Reported from other sites in } \\
\text { northwestern India }\end{array}$ \\
\hline $\begin{array}{l}\text { Cervus duvaucelii } \\
\quad \text { Cuvier, } 1823\end{array}$ & swamp deer, barasingha & $\begin{array}{l}\text { Mehrgarh, Loteshwar?, Bagor, } \\
\text { Dholavira? }\end{array}$ \\
\hline $\begin{array}{l}\text { Cervus unicolor } \\
\quad \text { Kerr, } 1792\end{array}$ & sambar & Bagor \\
\hline $\begin{array}{l}\text { Axis axis } \\
\quad \text { Erxleben, } 1777\end{array}$ & chital, spotted deer & $\begin{array}{l}\text { Mehrgarh, Loteshwar, Bagor, } \\
\text { Dholavira }\end{array}$ \\
\hline $\begin{array}{l}\text { Axis porcinus } \\
\quad \text { Zimmermann, } 1780\end{array}$ & hog deer & Loteshwar, Bagor \\
\hline $\begin{array}{l}\text { Muntiacus muntjak } \\
\text { Zimmermann, } 1780\end{array}$ & muntjak, barking deer & $\begin{array}{l}\text { Reported from other sites in } \\
\text { northwestern India }\end{array}$ \\
\hline $\begin{array}{l}\text { Sus scrofa cristatus } \\
\text { Wagner, } 1839\end{array}$ & Indian wild boar & $\begin{array}{l}\text { Mehrgarh, Loteshwar, Santhli?, } \\
\text { Bagor, Dholavira? }\end{array}$ \\
\hline $\begin{array}{l}\text { Equus hemionus } \\
\text { Pallas, } 1775\end{array}$ & Indian wild ass, onager & $\begin{array}{l}\text { Mehrgarh, Loteshwar, } \\
\text { Dholavira }\end{array}$ \\
\hline
\end{tabular}

Bagor (Thomas, 1977); Dholavira (Patel, 1997; 2015); Loteshwar (Patel, 2009); Mehrgarh (Meadow, 1993); Nausharo (sheep only: Meadow, 1989); Santhli (Patel and Meadow, 1998). See Roberts (1997) and Menon (2009) for information on the mammals of India and Pakistan, respectively. For other sites in northwestern India, see Thomas (2002). 
of superimposed deposits that include nine phases of habitation remains alternating with burials. Dug into the earliest habitation level were three elliptical pit-graves of women who had been buried with goats under three months old arranged in semicircles around their flexed legs. Two of the graves yielded five kids with the third having four kids (C. Jarrige et al., 1995; J.-F. Jarrige et al., 2013). The ability to obtain these numbers of young animals to place together in human interments indicates ready access to breeding stock, indicating that at least some goats were managed, in the process of domestication, or domesticated (sensu Zeder, 2015).

Breadth and depth dimensions of fused postcranial bones from habitation debris demonstrate that a wide range of goat sizes are represented in Period I, with the larger end of the size continuum disappearing by the end of the Aceramic Neolithic. One interpretation of this body-mass reduction through time is that, during the course of the Period I, kill-off in a single population of increasingly managed goats shifted from being non-targeted to being focused on young males (the unfused elements of which were not measured). Another is that two populations of goats are represented in the faunal assemblage, namely, a husbanded one and a hunted one. Domestic stock might have been brought to the site by its original settlers, who also hunted local wild goats along with the eleven other ungulates that have been identified from the site (Table 18.1). Over time, the contributions of hunted stock decreased while those of domestic stock increased. Indeed, a decrease in wild mammal bone percentages is clearly attested through the course of Period I and into later periods at Mehrgarh, with the assemblage becoming dominated by the remains of domestic cattle, sheep, and goat (Meadow, 1981; 1993).

Populations of wild goat or bezoar are still found in southern Balochistan including in the highlands west of Mehrgarh (Roberts, 1997). Analysis of the mitochondrial DNA (mtDNA) recovered from twenty-eight bezoars from that region has shown that some animals have 'wild' haplotypes not included in any modern domestic goat haplogroup, while others have haplotypes that group with today's domestic $\mathrm{C}$ and $\mathrm{F}$ haplogroups (Naderi et al., 2008). Based on mtDNA evidence from $\mathrm{C}$ haplogroup bezoars of southern and eastern Iran, Naderi and colleagues suggest that population expansion took place from that area during the Neolithic, which included animals being translocated northwest during a first phase of management or 'incipient domestication' on the Iranian plateau. Such an interpretation is predicated on movement of animals and accompanying human interaction across much of the Iranian plateau west to the Zagros Mountains and eastern Anatolia and east to the margins of the Indus valley, which is not improbable.

That said, the complexity of interpreting modern wild goat mtDNA distribution is exemplified by haplotype 134 within the $\mathrm{F}$ haplogroup. The five specimens reported with this haplotype each come from different highland localities between eastern Turkey and western Sindh, with the Pakistan specimen being the most geographically isolated (Naderi et al., 2008). Such a situation might result from the movement of captive wild or managed females over long distances and subsequent breeding with local wild males or through feralization of domesticates with that haplotype. In this regard the absence 
of evidence for the common domestic mtDNA haplogroups A and B introgressing into the wild populations of Balochistan is intriguing. Given the limitations of mtDNA for providing a comprehensive picture of phylogenetic history, however, approaches to the genetic study of goats in the Mehrgarh area would be well served to include both Ychromosome and autosomal analyses of modern domestic and wild samples together with ancient DNA studies on archaeofaunal specimens.

\section{Sheep}

The phylogeography and evolutionary history of different sheep is more complicated than for goats. The wild sheep found today in the mountains of eastern Balochistan is the urial (Ovis vignei), a species with a chromosome number $(2 \mathrm{n}=58)$ that differs from that of the Asiatic mouflon (Ovis orientalis $2 \mathrm{n}=54$ ). In spite of such long recognized cytogenetic differences, only recently have debates about relationships between wild sheep been clarified by mtDNA, Y-chromosome, and autosomal studies of modern forms, with the urial and mouflon seen as having diverged deep in the past (e.g. Meadows and Kijas, 2009; Rezaei et al., 2010; Meadows et al., 2011). Although genetic relationships between wild and domestic forms remain less well understood than for goats, researchers generally agree that one or more mouflon population(s) within their range of distribution in western Asia provided the original ancestors for modern domestic sheep. Nevertheless, animals of another species of sheep might have been managed or even domesticated in another region.

The Asiatic mouflon today is an animal of highland and foothill zones of Southwest Asia, with its range extending into eastern Iran where there is a zone of hybridity with the urial. The urial continues to be found north from Balochistan into the highlands of the Punjab and then northwest into Afghanistan and southern Central Asia and northeast into Kashmir. Urial and mouflon likely remained reproductively isolated until the Holocene, during which the retreat and eventual destruction of forests removed an effective barrier between the species (Valdez et al., 1978). Over what period of time that may have occurred is not clear, nor is it known whether the current distribution of these forms today is close to the same that it was in the past.

One possibility is that past ranges of distribution were different, with the mouflon early in the Holocene extending farther to the east and the urial being a more northern form that later spread south, where the two came to interbreed and produce fertile offspring. There is weak zooarchaeological support for this scenario in the form of a single wild sheep horn-core from the third-millennium cal BC site of Nausharo, located near Mehrgarh. The specimen has an overall morphology closer to the mouflon than to the urial (Meadow, 1989). Unfortunately, well-preserved horn-cores from archaeological sites in the region are rare and, in addition, we have inadequate understanding of variability in both modern and ancient horn-core morphologies.

The earliest evidence for sheep exploitation comes from the basal deposits excavated at Mehrgarh. By the middle of the Aceramic Neolithic (Period I) and continuing 
through the Ceramic Neolithic (Period II), sheep bones are at least as common as those from goats. In contrast to goats, however, only large-bodied individuals are represented in the early Neolithic. Sheep remains were not placed in burials, which lends support to an interpretation that their relationship to humans was initially different than that of goats. Furthermore, specimens from small-bodied sheep only begin to occur after the middle of the Aceramic Neolithic and do not dominate sheep assemblages until the Chalcolithic (Period III: mid-fifth millennium cal вс). By that time there are very few specimens from large-bodied animals (Meadow, 1981; 1993).

The rather abrupt appearance of bones from smaller-bodied sheep in the later levels of Mehrgarh Period I may indicate a change in exploitation practices to include greater numbers of sub-adult or adult ewes. This occurred at the same time that kill-off of large sheep continued. Such a pattern of exploitation may be interpreted as initial hunting followed by management and eventual domestication of sheep populations from local stock. This might be considered a 'directed pathway' to domestication (sensu Zeder, 2015), in which experience with an already domesticated animal (goat) forms the foundation for the intentional domestication of a local wild species (Option 1). Another possibility is that the hunting of wild populations during the early Aceramic Neolithic was followed by continued hunting through the end of the Neolithic combined with the exploitation of stock already domesticated elsewhere and introduced to the Mehrgarh area (Option 2).

Option 1 flies in the face of a widely held belief in a single zone in western Asia for sheep domestication. While the earliest levels of Mehrgarh are later than the beginning of the sheep domestication process in the west, the site's inhabitants had experience with the domestic goat as well as with wild sheep and goats. In addition, genetic studies are making it increasingly clear that there have been varying degrees of introgression between wild and domestic forms in the past. Whether the wild sheep in the Mehrgarh area was the urial or a hybrid, just because there is no genetic signature of such a form in modern sheep is not sufficient reason to eliminate local domestication as a possibility. Original domestic stock in the region were likely replaced or genetically swamped when wool sheep were developed and became widely favoured across much of Eurasia. The rather abrupt appearance of bones from small sheep toward the end of the Aceramic Neolithic, however, might favor Option 2-importation of domestic stock from elsewhere, although Option 1-local domestication-could also lead to rapid size diminution if animals were isolated from wild stock and kept under conditions of nutritional stress.

\section{Goat and Sheep beyond Balochistan}

By the mid-fourth millennium cal BC, remains of domestic sheep and goats have been identified from ancient settlements across northwestern South Asia beyond the zones of distribution of their wild forms. Together with cattle and crop plants, they became part of the foundation of an agro-pastoral economy that developed and flourished in this 
area through the period of the Indus civilization and beyond (e.g. Meadow, 1991; Patel, 1997; Meadow and Patel, 2002; Thomas, 2002; Chase, 2010). Understandings of the antecedents to the fourth-millennium cal вс sites, as well as their founding, development, and chronology remain rudimentary. Also poorly understood is the nature of the interactions that inhabitants of fourth-millennium cal BC agro-pastoral settlements had with peoples represented at more ephemeral and episodically occupied contemporary sites termed 'Mesolithic' - or better 'Microlithic', some of which had begun to be occupied at least by the eighth millennium cal вс (Patel, 2008).

Microlithic sites are typically situated atop stabilized sand dunes in arid and semiarid environments to the east and southeast of the Indus alluvium through southern Rajasthan and into North Gujarat. These sites are seen as representing populations distinct from those living in more substantial settlements. They are characterized by relatively shallow cultural deposits without significant structural remains and by sediments that appear quite homogeneous, making it difficult to define stratigraphic units. They often have multiple components, termed 'phases' or 'periods', which are differentiated on the basis of cultural material. All components share a microlithic tool industry, which in later phases may be supplemented by ceramics and by metal implements of copper/bronze or iron. It is often not clear whether the deposits within each phase represent a single continuous occupation or might reflect multiple short-term resettlements through time. Each component is often seen as leading directly into the next without consideration of whether there might be temporal gaps between them.

Further complicating understandings of microlithic sites are issues related to identification of the faunal remains. What has not been recognized until recently is the interpretative significance of the difficulties inherent in distinguishing not only bones of sheep from those of goats, but from comparably sized wild bovids such as blackbuck and chinkara and even from deer such as the chital and hog deer (Table 18.1). This methodological issue has been explored in the literature (e.g. Meadow, 1996; Meadow and Patel, 2003; Patel, 2009) and, especially when combined with unrecognized depositional mixing, has significant implications for understanding dune-top occupations throughout the northwest and for the timing and processes of introduction of sheep and goat into the region.

For example, at the site of Bagor in the Mewar region of southwestern Rajasthan (Misra, 1973), up to $60 \%$ of the faunal materials from Microlithic Phase I (dating from the sixth millennium cal BC) have been identified as coming from domestic animals (primarily goat and sheep but also cattle and pig: Thomas, 1977). These problematic identifications for goat and sheep have led to suggestions that such animals were obtained by the microlithic hunter-gatherers from as far away as contemporary settlements on the western margins of the Indus plain (Possehl, 1999) or even that they were domesticated locally within the context of an in situ transformation from hunting-gathering to use of domesticated forms (Shinde et al., 2004; and also Shinde, 2008 for the site of Gilund). Both scenarios seem unlikely.

In contrast, at the site of Loteshwar in North Gujarat careful consideration of site formation processes, dating, and faunal characterization has helped to understand some 
of the characteristics of dune-top Microlithic sites in the region. Loteshwar has two components-an Aceramic Microlithic (Period I) underlying a Chalcolithic (Period II) with no evident stratigraphic discontinuity between the two. The Period II deposits included pits that were dug into the Period I sediment. As a result, Aceramic Microlithic cultural materials, including lithics and bones, were incorporated into the later levels of the site by the Chalcolithic pit-diggers. Carefully selected animal bone samples from unmixed Period I deposits and from three Period II pits generated two series of radiocarbon dates that provide both the time spans for each component and a c.1,00o year gap between the Aceramic Microlithic (c.7300-4700 cal вC) and Chalcolithic (c.3700-2200 cal BC) (Patel, 2008). The duration of each period and the shallowness of the deposits, taken together, indicate a depositional history of multiple episodic occupations within each component. Faunal identifications based on comparative osteology show that the Period I assemblages are dominated by the remains of blackbuck along with specimens of nine other wild ungulates (Patel, 2009) (Table 18.1). More importantly, no sheep or goat bones were identified from these deposits (Patel, 2008). Indeed, no Microlithic component of any North Gujarat site for which the fauna has been studied has provided evidence for sheep or goat.

Details of the spread of domestic goat and sheep from Balochistan into the remainder of northwestern South Asia are limited. By the third millennium cal BC, however, it is possible to discern differences between populations in different areas that likely reflect local environmental conditions and/or pastoral practices. For example, at Nausharo (Balochistan) and Dholavira (Kutch, Gujarat), both situated in hot arid zones, the frequency of sheep remains is similar to those for goats. In contrast, at Harappa in betterwatered Punjab, the remains of sheep greatly outnumber those for goats. Furthermore the sheep at both Nausharo and Dholavira were smaller-bodied than at Harappa, where the sheep included many heavily built animals. This could reflect the development of regional breeds (Meadow, 1991; Patel, 1997). The third millennium cal BC was also a time of increased interactions across the whole of West Asia, which could have included the introduction of new breeds from outside the region and hybridization with local forms.

\section{Cattle}

While South Asia is at the eastern and southern margins of the distribution of wild Ovis and Capra, it forms the western part of the Indo-Malayan arc that includes all of the extant wild taxa of the genera Bos and Bubalus. In the past it was also home to nowextinct Bos namadicus (sometimes designated as Bos primigenius namadicus), which is likely to have been the ancestor of domestic zebu cattle (Bos indicus) (e.g. Grigson, 1985). Notable by its hump, drooping ears, and large dewlap, the domestic zebu is also characterized by a physiology that makes it able to tolerate heat stress better than taurine cattle (Bos taurus) (Hansen, 2004). Thus it is well adapted to tropical and subtropical regions from eastern Iran to southern China and throughout both mainland and island 
Southeast Asia, where it continues to be the dominant form of domestic cattle.

A case can be made from the archaeofaunal record for the local domestication of zebu in northwestern South Asia by considering both changes in size and proportion and in taxonomic abundance. Cattle bone breadths and depths can be used to track body mass change and bone lengths to evaluate stature (Meadow, 1981; 1993). Through the Aceramic Neolithic (Period I) at Mehrgarh, diminution in stature is attested in both median and smallest values. In the earliest levels, the few length measurements available are all from tall animals. Bones from shorter individuals are first encountered in the middle levels, with their numbers increasing through the end of the Aceramic and into the Ceramic Neolithic (Period II). During this same time frame, specimens from the largest-stature animals become increasingly rare, although the infrequent tall individual is still represented through the Chalcolithic (Period III). A similar pattern can be seen in the breadth and depth measurements. Diminution in body mass is attested by the increasing numbers of smaller-sized bones in the last phases of Period I and continuing through Period II. Bones from the heaviest animals largely disappear by the beginning of the Ceramic Neolithic. This can be interpreted as cattle becoming more gracile, which could reflect changes in diet and activity level.

As for taxonomic abundance, cattle bones are not common in the earliest levels of Aceramic Neolithic Mehrgarh ( $<5 \%)$. By the end of Period I, however, they make up between $40 \%$ and $60 \%$ of the ungulate remains. Similarly high proportions continue into later periods at Mehrgarh and are characteristic of many fourth-, third-, and second-millennium cal BC sites in northwestern South Asia as well as elsewhere in India, reflecting the importance of cattle for both primary and secondary products (Patel, 1997; Thomas, 2002; Meadow and Patel, 2003).

The duration of Period I at Mehrgarh was as long as 1,500 years, which would have provided ample time for increasingly intensive animal management to develop into captive breeding leading to body-size reduction. The parallel trends of increasing exploitation and diminution in both body mass and animal height through time are consistent with an interpretation of local cattle domestication. The process may have begun with management of females and later incorporated the use of male offspring for breeding. There are other possible scenarios as well, including capturing and raising wild infants, but a problem with cattle as opposed to other bovids is that there are no extant wild populations, the behaviours of which could be employed as models for the past.

Evidence for the cattle at Mehrgarh sharing a similar phenotype to modern Bos indicus is varied. Zygomatic bones from Periods I and II all have the flat orbital rim that is a 'fairly good indicator for indicus skulls' in older animals (Grigson, 1980: 23). In addition, from Late Period I come a partial skull with intact occipital region that has zebu morphology as well as a gracile bifid thoracic vertebra of the type characteristic of zebu. Finally, also from Late Period I, there is a clay cattle figurine with a pronounced hump, which is the earliest known in a long tradition of making zebu figurines in South Asia (Meadow, 1981; 1993).

The taxonomic relationship between taurine and zebu cattle was debated since at least 1758, when Linnaeus assigned them to the different species Bos taurus L. and Bos indicus 
L. based on their morphological differences. Darwin (1868: 80; see also 1859: 28) supported the position of Linnaeus, writing: 'there can hardly be a doubt, notwithstanding the adverse opinion of some naturalists, that the humped and non-humped cattle must be ranked as specifically distinct'. The differences of opinion on zebu origins continued up to the 1990s, when genetic analyses of modern zebu and taurine cattle resolved the issue, showing that the genetic differences between the two forms are too great to have taken place within the time frame of the Holocene. In a remarkably comprehensive approach for the time, studies included analysis of mitochondrial DNA, Y-chromosomes, and autosomal microsatellites (e.g. Loftus et al., 1994; Bradley et al., 1996; MacHugh et al., 1997; Bradley et al., 1998), with subsequent work bringing out the complex genetic structures and histories of various cattle populations (for a review, see Magee et al., 2014).

Two major mtDNA haplogroups have been defined for modern zebu: I1 (= Z1) and I2 $(=\mathrm{Z} 2)$. Analyses of diversity within each haplogroup suggest that northwestern South Asia is the best candidate for the origin of the dominant haplogroup I1 and thus for zebu domestication. I1 is also the dominant haplogroup in other parts of India as well as throughout Southeast and East Asia. Haplogroup I2 shows a more complex pattern of regionalized genetic diversity, which may have resulted from domestication(s) of individuals from one or more wild I2 populations or from introgression through recruitment of local wild I2 females into domestic stock in various parts of India (Baig et al., 2005; Magee et al., 2007; Chen et al., 2010).

In contrast, only one haplogroup $\left(\mathrm{Y}_{3}\right)$ has been identified in zebu Y-chromosomes (Götherstörm et al., 2005). That haplogroup has very low haplotype diversity, which suggests high genetic uniformity among Asian zebu ancestral male breeding stock. This in turn supports a single domestication hypothesis for males and introgression through the crossing of domestic bulls with wild cows to account for the mtDNA diversity noted above (Pérez-Pardal et al., 2010).

Autosomal SNP-based demographic modeling has also presented a complex domestication history for zebu (Murray et al., 2010). This includes an initial domesticationrelated bottleneck in the Holocene, followed by population-size recovery and subsequent admixtures from the ancestral South Asian wild cattle population. Yet, the genetic complexity of zebu also does not exclude the possibility of multiple wild ox ancestries contributing to two or more separate lines of domestication. And in addition to recruitment of local wild females into domestic herds, insemination of domestic females by wild males is indicated as a likely introgression scenario.

Taking an overall view of the implications of the genetic data for Bos indicus, a number of scenarios for domestication and subsequent breeding practices can be envisioned. These include single or multiple localities of management and eventual domestication; cross-breeding of wild males with domestic females and of domestic males with wild females, both leading to genetic introgression; crossing of domestic breeds; and feralizations of males and/or females. The problem with such data from modern domestic animals, however, is that they provide information based on the offspring of continued reproductive successes far removed in time from the period when domestication 
processes took place. They do not record unrealized or failed efforts, swamped or extinct genetic lines, or domestic population replacements. To address such issues requires study of ancient DNA. Given the absence of such data for South Asian cattle, it is not possible to understand the true complexity of zebu genetic and domestication history. That said, there is archaeofaunal evidence from parts of India and eastern Iran that can help us frame some of those complexities archaeologically.

At the site of Loteshwar in North Gujarat (discussed above), there is evidence for both wild and domestic forms of cattle. The cattle remains from the Aceramic Microlithic (Period I) are all exclusively from large-bodied wild animals. Those from the Chalcolithic (Period II) have considerably smaller dimensions and include the remains of some young animals. Three Period II cattle bones were directly dated. Two produced results between $c .3700$ and $3500 \mathrm{cal} \mathrm{BC}$ and one dated to between $c .2500$ and $2000 \mathrm{cal}$ $\mathrm{BC}$, showing that cattle pastoralism was practised in North Gujarat by the fourth millennium cal вС (Patel, 2008; 2009).

This Loteshwar evidence highlights a number of important issues. The presence of a wild form of cattle in the Aceramic Microlithic establishes that humans would have been familiar with wild cattle behaviour, which is an underlying prerequisite for local domestication. Potentially they also would have had access to young animals that could be more readily captured and managed. By the Chalcolithic, when domestic cattle are attested at Loteshwar, introgressions from local wild forms would also have been a possibility if wild cattle were still at hand. Given the diversity of mtDNA haplotypes represented in modern Bos indicus, introgressions may have occurred rather widely until the time of final extinction of the wild form Bos namadicus. Localities beyond the northwest that have been highlighted for introgressions include the Gangetic region of northern India as well as central and southern India (Chen et al., 2010). In these areas, however, evidence for cattle pastoralism begins to occur only in the third millennium cal BC, considerably later than at Loteshwar, which is among the earliest-dated sites with evidence for cattle pastoralism beyond the Mehrgarh area.

Whether cattle pastoralism developed locally in North Gujarat or was the result of groups making their way over time south through Sindh remains unclear. It is intriguing, however, that the ceramics found with the domestic cattle bones at Loteshwar are a local variety, not currently known from Sindh (Ajithprasad and Sonawane, 2011). Other outstanding issues are the nature of the shift from hunting and gathering to agriculture and pastoralism in the region and whether that change was a case of local populations making the transition, whether such groups were replaced by newcomers or whether processes of acculturation took place.

By the beginning of the third millennium cal $\mathrm{BC}$, domestic plant- and animalproducing economies were common across most areas of northwestern South Asia and by the middle of that millennium had given birth to the Indus civilization. Harappan iconography includes representations of humped and non-humped cattle, quite likely reflecting the important connections that peoples of northwestern South Asia had with contemporary agro-pastoral societies in Iran, Afghanistan, and beyond. Cross-breeding of zebu and taurine cattle could also have been taking place by that time, especially in 
the northwest. Such admixture is attested genetically in various modern breeds that have zebu or taurine phenotypes and is said to have considerable time depth (P. Kumar et al, 2003; Decker et al., 2014).

Two sites from southeastern Iran-Tepe Yahya and Shahr-i Sokhta-have provided evidence for zebu and for taurine cattle as well. From Tepe Yahya, twelve orbital rims have been illustrated and described (Meadow, 1986). Of these, one has a zebu-like morphology, one is taurine in its morphology and the other ten have morphologies that fall between the two. All date between between the mid-sixth and end of the fourth millennium cal $\mathrm{BC}$, with the most taurine-like specimen being the latest of the group. In addition, from the nearby site of Tepe Gaz Tavila comes a single bifid vertebra spine, dating to the mid-sixth millennium cal вс. Northeast of Tepe Yahya is the site of Shahr-i Sokhta dating from the late fourth to the late third millennium cal BC. Some of the complete cattle horn-cores from the site have been identified as coming from Bos namadicus based on their size and cross-sectional morphology and some of the metapodials are particularly gracile, a feature common in zebu. In addition, bifid thoracic vertebrae and humped-cattle figurines have been recovered from the site (Bökönyi, 1997).

Epstein (1971) has argued that the barriers posed by the central deserts of Iran provided the western limits of Bos namadicus distribution and that eastern Iran was a prime location for zebu domestication. Bökönyi (1997), while acknowledging the Mehrgarh evidence, notes that zebu could have been domesticated anywhere the wild form was present, including in eastern Iran. Larson and Burger (2013) argue that domestic zebu resulted from early cross-breeding of domestic taurine cattle from the west with Bos namadicus. Our proposal is that cattle from one or more wild populations in northwestern South Asia were brought under increasing human control beginning as early as the late eighth millennium cal вс. That said, it is important to emphasize that Bos primigenius and Bos namadicus are extinct, Bos taurus and Bos indicus are difficult to differentiate based on most of their skeletal parts, and that, to date, there is no archaeogenetic evidence from eastern Iran or South Asia. Because the archaeology of northwestern South Asia and eastern Iran is so poorly known for the first half of the Holocene, we understand little about the antecedents to Mehrgarh, Loteshwar, and Tepe Yahya. As a result, more robust answers to questions about changing human-cattle relations in the region will come only when it is possible to investigate that archaeological record in greater detail and to successfully extract and sequence ancient cattle DNA from the region.

\section{WATER BUfFAlO}

The domestic water buffalo (Bubalus bubalis) is another important large bovine of South and Southeast Asia that continues to have a major impact on the economies of the region and beyond. Two forms have been morphologically and genetically differentiatedthe river buffalo of much of South Asia and the swamp buffalo in northeastern India, 
Southeast Asia, and much of China. Unlike the case for cattle, the wild form (Bubalus arnee) is still extant although endangered, with isolated populations in parts of India, Nepal, Bhutan, Thailand, and Cambodia. There are also numerous wild-domestic crossbreeds (generally from domestic females breeding with wild males) and feral populations throughout the region (Barker, 2014; Choudhury, 2014).

Phenotypic differences between the river and swamp forms have been recognized in horn morphology. Swamp animals have outward- and backward-sweeping horns in the plane of the frontal, while river breeds have a variety of morphologies that share a downward and backward orientation with a more or less well-developed spiral (Mason, 1974). Other phenotypic differences, such as hair, skin, and body characteristics and development and behaviour, as well as geographic distribution, have also been observed (Mason, 1974; Cockrill, 1984). In addition, the two forms have been found to differ in their chromosome numbers with river buffalo being $2 \mathrm{n}=50$ and swamp buffalo being $2 \mathrm{n}=48$. Fertile hybrids occur routinely in areas where both occur. Both forms do well under hot conditions so long as they have access to sufficient standing or running water in which to wallow or swim or from which they can be doused to assist in thermoregulation.

Archaeologically, our understanding of water buffalo domestication and exploitation is limited. In northwestern South Asia, water buffalo postcranial specimens have been identified from the early levels of the Aceramic Neolithic at Mehrgarh (Period I), horncore fragments from the Ceramic Neolithic (Period II) and a complete horn-core from the Chalcolithic (Period III) (Meadow, 1981; Patel and Meadow, 1998). These specimens are considerably larger than those from modern domestic forms and likely came from wild animals. The horn-core morphology is similar to that of modern swamp and wild water buffalo.

Farther south on a low stabilized sand dune in the alluvial plains of North Gujarat east of the Little Rann of Kutch, an impressive collection of water buffalo remains was uncovered at the site of Santhli (Patel and Meadow, 1998). As at Loteshwar, Santhli has both an earlier Aceramic component with microliths and a later Chalcolithic one with human burials and ceramics, each component constituting a shallow deposit. Although not directly dated, the Santhli buffalo remains are likely to have been contemporary with some part of the Aceramic Microlithic at Loteshwar (mid-eighth to mid-fifth millennium cal $\mathrm{BC}$ ) because of similarities between the nature of the microlithic settlements and assemblages at the two sites. Indeed a few water buffalo postcranial specimens have been identified from the Aceramic Microlithic deposits at Loteshwar.

The Santhli water buffalo remains comprise clusters including both cranial and postcranial specimens from at least eight morphometrically wild animals (Patel and Meadow, 1998). Their horn-core morphologies are similar to those of domestic swamp buffalo and of extant wild water buffalo from India. Basal horn-core dimensions and postcranial measurements show that the Santhli animals were considerably larger than modern domestic forms and comparable in size to the wild water buffalo of Mehrgarh. Indeed, a particularly important feature of the Santhli assemblage is that it provides a unique mid-Holocene wild water buffalo standard with which other buffalo material can be compared. 
Within the clusters, in addition to conjoining cervical vertebrae, many of the postcranial bones are parts of articulated units from meat-poor zones of the appendicular skeleton. These joints may have been left behind by hunters who focused on the meatrich parts of the carcasses. Based on their mandibular tooth eruption and wear, five of these animals ranged in age from an infant to a young adult, while epiphyseal fusion of the limb-bones indicates an age-range from early juvenile into adult. The broad span of ages represented in this deposit with many articulated skeletal segments from a number of different animals can be interpreted in two ways. One is that this part of Santhli was a disposal area for the remains that accumulated over time from multiple hunts. The other is that the deposit resulted from a single catastrophic kill-off event possibly related to an animal drive. In either case, the deposits demonstrate that microlithic groups had access to wild water buffalo of different ages and were familiar with the animal's behaviour within the landscape of North Gujarat. This availability and knowledge could have been translated into management and eventual domestication of water buffalo in this region, a possibility that is explored below.

Also in Gujarat, on an island in the Great Rann of Kutch, is the urban Harappan settlement of Dholavira, which dates from the beginning of the third to the middle of the second millennium cal BC (Bisht, 2015). Bovines contributed between 50 and $70 \%$ of the faunal remains from deposits of occupation Stages III through V (between $c .2800$ and $2000 \mathrm{cal} \mathrm{BC}$ ) (Patel, 1997). In the subset of those bones sufficiently diagnostic to permit differentiation between the two bovine taxa, the proportions of cattle to water buffalo vary depending on time period and context but generally favour cattle (Patel, 1997; 2015). Measurements of postcranial specimens show that almost all water buffalo bones come from animals comparable in size to modern domestic forms, with only two elements from buffalo of a size similar to those represented at Santhli and Mehrgarh (Patel and Meadow, 1998). Small-bodied animals such as those represented at Dholavira would have resulted from processes of animal management that ultimately led to water buffalo domestication. These are likely to have taken place sometime between the sixth and fourth millennium cal BC, a timeframe for which the archaeofaunal record is inadequate to provide meaningful information on changing human-water buffalo interactions.

Although water buffalo remains have been identified from Harappan period sites across much of northwestern South Asia (summarized in Thomas, 2002), such high proportions as those documented at Dholavira have not been reported elsewhere. For example, only a very few specimens have been identified in the bovine-rich assemblages from Balakot near the Arabian Sea coast in eastern Balochistan (Meadow, 1979) and from Harappa in Pakistani Punjab (Meadow, 1991). Even so, at Harappa and other Indus sites north of Gujarat, water buffalo are well represented in the iconography of stamp seals and terracotta figurines, which indicates their familiarity and significancewhether practical or conceptual-to local populations. The frequency of their remains in the faunal assemblages at Dholavira reflects their practical importance to the local economy. The site was constructed with water harvesting and storage facilities to mitigate its location on an island without perennial rivers in an area that receives fluctuating amounts of rainfall on an irregular basis (Bisht, 2005). This water-centric focus 
of Dholavira would have been ideal for keeping water buffalo that require moisture for thermoregulation (Patel, 1997).

Given the evidence for wild buffalo in North Gujarat and for both wild and especially domestic populations at Dholavira, this region is important to explore for evidence of local water buffalo domestication. In considering that process, however, there are some outstanding phenotypic and genotypic issues that also need to be explored. The iconographic and archaeofaunal evidence both show horn morphologies like those of modern swamp and wild buffalo but not like those of river buffalo, even though it is the latter that dominate much of India today. Genetic studies have confirmed that phenotypic characteristics are not always reliable for identifying to which water buffalo form a modern individual, breed, or population belongs. For example, the domestic Chilika and Toda buffalo populations of eastern and southern India, respectively, were generally believed to be of swamp type based on phenotypic and behavioural characteristics. Cytogenetic, microsatellite, and mtDNA analyses, however, all show that both breeds group with riverine buffalo (e.g. Nair et al., 1986; S. Kumar et al., 2006; Mishra et al., 2009; Kathiravan et al., 2011). In another genetic study, a sample of ten Nepalese wild buffalo with swamptype morphology including horn shape were found to share a genetic structure with river buffalo. Microsatellite analysis also determined that the animals tested included eight wild and two wild-domestic hybrids (Flamand et al., 2003; Zhang et al., 2011).

Genetic approaches have also been employed to investigate the phylogenetic relationships between modern river and swamp buffalo in order to illuminate their domestication histories. S. Kumar and colleagues (2007a; 2007b) approached these issues and determined that there is a sufficiently high degree of mtDNA sequence divergence between river and swamp buffalo to separate them into two clades. The divergence was determined to be comparable to that between Bos indicus and Bos taurus. A similar degree of divergence was also found to be represented in the Y-chromosome (Yindee et al., 2010). Time of divergence has been variously estimated, and all results indicate that the two wild ancestral populations from which modern domestic water buffalo descended had diverged well before domestication occurred. S. Kumar and colleagues (2007a; 2007b) also suggest independent domestication of river and swamp buffalo. They interpret the complexity of mtDNA genetic structure in modern river buffalo to indicate that there has been continuous introgression of wild animals into domestic stock in South Asia from early in the domestication process (also Nagarajan et al., 2015).

Unfortunately, there is limited archaeological evidence from eastern India through southern China to bring to bear on the question of swamp buffalo domestication. What information there is comes from southern China and Thailand and it indicates that domestic buffalo may not have become economically important or even present there until the late first millennium cal вс (Higham, 2012; Yue et al., 2013). If valid, this late date underscores a significant difference in the domestication histories of river and swamp buffalo, raises the issue of the impetus for domestication of the swamp form, and underlines the need for increased understandings of interactions between South and East Asia during the second half of the first millennium cal вс. 
In addition to the genetic studies focusing on modern river buffalo cited previously, there have been a number of similar analyses carried out on swamp buffalo particularly in China (e.g. Lei et al., 2011; Zhang et al., 2011; Yue et al., 2013) but also in northeastern India (Mishra et al., 2015). Missing from these studies, however, with the exception of that on Nepalese animals (noted previously), is genetic evidence from modern wild buffalo populations. Such studies would provide insights into the genetic structure and variability within and between different wild buffalo populations as well as into their relationships to modern domestic forms. Genetic introgression from the domestic into the wild is a significant issue for conservation of the endangered wild buffalo today. It continues to occur with farmers turning out their females to breed with wild males, which if not retrieved, can give birth to F1 hybrids that join the wild herd (Barker, 2014). This and other pathways to introgression and admixture would have occurred in the past including between river and swamp forms, as has been demonstrated for some modern populations in northeastern India, Nepal, China, and Southeast Asia (Zhang et al., 2011; Mishra et al., 2015).

Understanding processes of water buffalo domestication are still in their infancy. They are hampered by a dearth of zooarchaeological studies that focus on the bovines of South and Southeast Asia and by the difficulties inherent in reliable taxonomic identification of their remains. In northwestern South Asia, there is evidence for thirdmillennium cal вС water buffalo domesticates and for the presence of contemporary and earlier wild forms. Yet the archaeological record for the sixth, fifth, and fourth millennia cal BC that would be key for investigating domestication processes remains sparse. While the modern genetic data and their interpretation are intriguing in the complexities that they reveal, their relevance for understanding the various facets of the ancient situation is limited, and no ancient DNA research on South Asian water buffalo remains has been successfully carried out to date.

\section{CONCLUSIONS}

Animal domestication was a complex process of developing human-animal relationships and behaviours that varied according to the animal form and the human population involved under specific circumstances at any given time and in any given place. In the preceding pages, we have highlighted some of these complexities by exploring aspects of the archaeological, zooarchaeological, and genetic evidence for the domestication of goat, sheep, zebu cattle, and water buffalo in northwestern South Asia.

Almost all the earliest evidence for the transition from exploiting wild fauna to the development of animal husbandry comes, to date, from one site-Mehrgarh — and that only for goat, sheep, and cattle. In other areas to the east and south, remains of shallow and episodic occupations from the eighth through the fifth millennium cal BC are those of hunter-gatherers who exploited the diverse wild resources of the region, as seen at the sites of Loteshwar and Santhli. The spread of goat and sheep outside the zone of their 
wild relatives likely would have taken place by the fourth millennium cal BC as the result of the movement of herders or agro-pastoralists or through trade, although there is no archaeological evidence for the nature of the processes involved. For cattle, since the distribution of the wild form as attested in the archaeofaunal record included most of South Asia, the possibility existed for local management leading to domestication. This could have been accompanied by periodic exchange of genetic material between domestic animals and their free-ranging relatives. While wild cattle are extinct, wild water buffalo are still found in South Asia. Remains of domestic or wild buffalo have been identified from a number of sites in the northwest, but the bulk of zooarchaeological evidence comes from Gujarat-for wild animals from Santhli and for domesticates from Dholavira. Management leading to domestication likely took place sometime from the sixth to fourth millennia, possibly in Gujarat. Although direct evidence for this process is lacking, it could have involved long-term genetic exchange due to cross-breeding between wild, managed, and domestic forms.

Thus, for these animals there is no common narrative, but there are some common challenges in the context of South Asia. These include lack of adequate archaeological evidence for key time periods especially that between the sixth and fourth millennium cal BC, difficulties in differentiating the remains of similar-sized bovid species, and poor preservation of ancient DNA. A final challenge is to not underestimate variability and complexity in past human behaviour in the region.

\section{ACKNOWLEDgements}

Our synthesis is a reflection of research carried out over many years that was encouraged and facilitated by many friends and colleagues from various institutions and supported by funding sources too numerous to individually acknowledge here. They are extensively credited in our various publications that are included in the bibliography. Here the authors wish to thank Umberto Albarella along with Hannah Russ, Mauro Rizzetto, Kim Vickers, and Sarah Viner-Daniels for inviting us to contribute our essay and for all the hard work that they have put in to getting this volume ready. In particular we would like to thank Umberto for his utmost patience and understanding while we were drafting a paper that came to take on a life of its own. We dedicate this contribution to the memory of Jean-François Jarrige, whose extensive work at archaeological sites in Balochistan, including Mehrgarh, provided the solid foundations needed to better understand the development of major cultural phenomena in northwestern South Asia.

\section{REFERENCES}

Ajithprasad, P. and Sonawane, V. H. (2011) 'The Harappa culture in North Gujarat: a regional paradigm', in Osada, T. and Endo, H. (eds) Linguistics, Archaeology, and Human Past, pp. 223-69. Kyoto: Research Institute for Humanity and Nature. 
Baig, M., Beja-Pereira, A., Mohammad, R., Kulkarni, K., Farah, S., and Luikart, G. (2005) 'Phylogeography and origin of Indian domestic cattle', Current Science, 89(1), 38-40.

Barker, J. S. F. (2014) 'Genetics of wild water buffalo', in Melletti, M. and Burton, J. (eds) Ecology, Evolution and Behavior of Wild Cattle, Box 16.1. Cambridge: Cambridge University Press.

Bisht, R. S. (2005) 'The water structures and engineering of the Harappans at Dholavira (India)', in Jarrige, C. and Lefèvre, V. (eds) South Asian Archaeology 2001, Vol. 1, pp. 11-25. Paris: Éditions Recherche sur les Civilisations.

Bisht, R. S. (2015) Excavations at Dholavira 1989-9o to 2004-2005, New Delhi: Archaeological Survey of India.

Bökönyi, S. (1997) 'Zebus and Indian wild cattle', Anthropozoologica, 25-6, 647-54.

Bradley, D. G., MacHugh, D. E., Cunninghan, P., and Loftus, R. T. (1996) 'Mitochondrial diversity and origins of African and European cattle', Proceedings of the National Academy of Sciences of the United States of America, 93, 5131-5.

Bradley, D. G., Loftus, R. T., Cunningham, P., and MacHugh, D. E. (1998) 'Genetics and domestic cattle origins', Evolutionary Anthropology, 6(3), 79-86.

Chase, B. (2010) 'Social change at the Harappan settlement of Gola Dhoro: a reading from animal bones', Antiquity, 84, 528-43.

Chen, S., Lin, B.-Z., Baig, M., Mitra, B., Lopes, R. J., Santos, A. M., Magee, D. A., Azevedo, M., Tarroso, P., Sasazaki, S., Ostrowski, S., Mahqoub, O., Chaudhuri, T. K., Zhang, Y. P., Costa, V., Royo, L. J., Goyache, F., Luikart, G., Boivin, N., Fuller, D. Q., Mannen, H., Bradley, D. G., and Beja-Pereira, A. (2010) 'Zebu cattle are an exclusive legacy of the South Asia Neolithic', Molecular Biology and Evolution, 27(1), 1-6.

Choudhury, A. (2014) 'Wild water buffalo Bubalus arnee (Kerr, 1792)', in Melletti, M. and Burton, J. (eds) Ecology, Evolution and Behavior of Wild Cattle, pp. 255-301. Cambridge: Cambridge University Press.

Cockrill, W. R. (1984) 'Water buffalo', in Mason, I. L. (ed.) Evolution of Domesticated Animals, pp. 52-63. London: Longman.

Darwin, C. (1859) On the Origin of Species by Means of Natural Selection, London: John Murray.

Darwin, C. (1868) The Variation of Animals and Plants under Domestication, Vol. 1, London: John Murray.

Decker, J. E., McKay, S. D., Rolf, M. M., Kim, J.-W., Molina Alcalá, A., Sonstegard, T. S., Hanotte, O., Götherström, A., Seabury, C. M., Praharani, L., Ellahi Babar, M., Correia de Almeida Regitano, L., Ali Yilzid, M., Heaton, M. P., Liu, W.-S., Lei, C.-Z., Reecy, J. M., SaifUr-Rehman, M., Schnabel, R. D., and Taylor, J. F. (2014) 'Worldwide patterns of ancestry, divergence, and admixture in domesticated cattle', PLOS Genetics, 10(3), DOI: 10.1371/journal.pgen.1004254.

Epstein, H. (1971) The Origins of Domestic Animals of Africa, revised edn, New York: Africana Publishing.

Flamand, J. R. B., Vankan, D., Gairhe, K. P., Duong, H., and Barker, J. S. F. (2003) 'Genetic identification of wild Asian water buffalo in Nepal', Animal Conservation, 6, 1-10.

Fuller, D. Q. and Madella, M. (2002) 'Issues in Harappan archaeobotany: retrospect and prospect', in Settar, S. and Korisettar, R. (eds) Indian Archaeology in Retrospect: Protohistory, Vol. 2, pp. 317-90. New Delhi: Indian Council of Historic Research \& Manohar.

Götherstörm, A., Anderung, C., Hellborg, L., Elburg, R., Smith, C., Bradley, D. G., and Ellegren, H. (2005) 'Cattle domestication in the Near East was followed by hybridization with aurochs bulls in Europe', Proceedings of the Royal Society B, 272, 2345-50.

Grigson, C. (1980) 'The craniology and relationships of four species of Bos: 5. Bos indicus L.', Journal of Archaeological Science, 7, 3-32. 
Grigson, C. (1985) 'Bos indicus and Bos namadicus and the problem of autochthonous domestication in India, in Misra, V. N. and Bellwood, P. (eds) Recent Advances in Indo-Pacific Prehistory, pp. 425-8. New Delhi: Oxford \& IBH.

Hansen, P. J. (2004) 'Physiological and cellular adaptations of zebu cattle to thermal stress', Animal Reproduction Science, 82-3, 349-60.

Higham, C. (2012) 'The long and winding road that leads to Angkor', Cambridge Archaeological Journal, 22(2), 265-89.

Jarrige, C., Jarrige, J.-F., Meadow, R. H., and Quivron, G. (eds) (1995) Mehrgarh Field Reports 1974-1985 from Neolithic Times to the Indus Civilization, Karachi: Department of Culture and Tourism, Government of Sindh.

Jarrige, J.-F., Jarrige, C., and Quivron, G. (2013) Mehrgarh Neolithic Period Seasons 1997-200o, Paris: Éditions de Boccard.

Kathiravan, P., Kataria, R. S., Mishra, B. P., Dubey, P. K., Sadana, D. K., and Joshi, B. K. (2011) 'Population structure and phylogeography of Toda buffalo in Nilgiris throw light on possible origin of aboriginal Toda tribe of South India, Journal of Animal Breeding and Genetics, 128, 295-304.

Kumar, P., Freeman, A. R., Loftus, R. T., Gaillard, C., Fuller, D. Q., and Bradley, D. G. (2003) 'Admixture analysis of South Asian cattle', Heredity, 91, 43-50.

Kumar, S., Gupta, J., Kumar, N., Dikshit, K., Navani, N., Jain, P., and Nagarajan, M. (2006) 'Genetic variation and relationships among eight Indian riverine buffalo breeds', Molecular Ecology, 15, 593-600.

Kumar, S., Nagarajan, M., Sandhu, J. S., Kumar, N., Behl, V., and Nishanth, G. (2007a) 'Mitochondrial DNA analyses of Indian water buffalo support a distinct genetic origin of river and swamp buffalo', Animal Genetics, 38, 227-32.

Kumar, S., Nagarajan, M., Sandhu, J. S., Kumar, N., and Behl, V. (2007b) 'Phylogeography and domestication of Indian river buffalo', BMC Evolutionary Biology, 7, 186.

Larson, G. and Burger, J. (2013) 'A population genetics view of animal domestication', Trends in Genetics, 29(4), 197-205.

Lei, C. Z., Zhang, C. M., Weining, S., Campana, M. G., Bower, M. A., Zhang, X. M., Liu, L., Lan, X. Y., and Chen, H. (2011) 'Genetic diversity of mitochondrial cytochrome b gene in Chinese native buffalo', Animal Genetics, 42, 432-6.

Linnaeus, C. (1758) Systema Naturae per Regna Tria Naturae, 1oth edn, Stockholm: Laurentii Salvii.

Loftus, R. T., MacHugh, D. E., Bradley, D. G., Sharp, R. M., and Cunningham, P. (1994) 'Evidence of two independent domestications of cattle', Proceedings of the National Academy of Sciences of the United States of America, 91, 2757-61.

MacHugh, D. E., Shriver, M. D., Loftus, R. T., Cunningham, P., and Bradley, D. G. (1997) 'Microsatellite DNA variation and the evolution, domestication and phylogeography of taurine and zebu cattle (Bos taurus and Bos indicus)', Genetics, 146, 1071-86.

Magee, D. A., Mannen, H., and Bradley, D. G. (2007) 'Duality in Bos indicus mtDNA diversity: support for geographical complexity in zebu domestication', in Petraglia, M. D. and Allchin, B. (eds) The Evolution and History of Human Populations in South Asia: InterDisciplinary Studies in Archaeology, Biological Anthropology, Linguistics and Genetics, pp. 385-91. Dordrecht: Springer.

Magee, D. A., MacHugh, D. E., and Edwards, C. J. (2014) 'Interrogation of modern and ancient genomes reveals the complex domestic history of cattle', Animal Frontiers, 4(3), 7-22. 
Mason, I. L. (1974) 'Species, types and breeds', in Cockrill, W. R. (ed.) The Husbandry and Health of Domestic Buffalo, pp. 1-47. Rome: Food and Agriculture Organization of the United Nations.

Meadow, R. H. (1979) 'Prehistoric subsistence at Balakot: initial consideration of the faunal remains', in Taddei, M. (ed.) South Asian Archaeology 1977, pp. 275-315. Naples: Istituto Universitario Orientale, Seminario di Studi Asiatici.

Meadow, R. H. (1981) 'Early animal domestication in South Asia: a first report of the faunal remains from Mehrgarh, Pakistan', in Härtel, H. (ed.) South Asian Archaeology 1979, pp. 14379. Berlin: Dietrich Reimer Verlag.

Meadow, R. H. (1986) 'Animal Exploitation in Prehistoric Southeastern Iran: Faunal Remains from Tepe Yahya and Tepe Gaz Tavila- $\mathrm{R} 37$ 5500-300o BC'. Unpublished PhD dissertation, Harvard University (Cambridge, Massachusetts).

Meadow, R. H. (1989) 'Prehistoric wild sheep and sheep domestication on the eastern margin of the Middle East', in Crabtree, P. J., Campana, D., and Ryan, K. (eds) Early Animal Domestication in Its Cultural Context. MASCA Research Papers in Science and Archaeology 6, Special Supplement, pp. 24-36. Philadelphia: University of Pennsylvania.

Meadow, R. H. (1991) 'Faunal remains and urbanism at Harappa', in Meadow, R. H. (ed.) Harappa Excavations 1986-1990: A Multidisciplinary Approach to Third Millennium Urbanism, pp. 89-106. Madison: Prehistory Press.

Meadow, R. H. (1993) 'Animal domestication in the Middle East: a revised view from the eastern margin', in Possehl, G. L. (ed.) Harappan Civilization: A Recent Perspective, and revised edn, pp. 295-320. New Delhi: Oxford \& IBH.

Meadow, R. H. (1996) 'The origins and spread of agriculture and pastoralism in northwestern South Asia, in Harris, D. R. (ed.) The Origins and Spread of Agriculture and Pastoralism in Eurasia, pp. 390-412. London: UCL Press.

Meadow, R. H. and Patel, A. K. (2002) 'From Mehrgarh to Harappa and Dholavira: prehistoric pastoralism in north-western South Asia through the Harappan period', in Settar, S. and Korisettar, R. (eds) Indian Archaeology in Retrospect: Protohistory, Vol. 2, pp. 391-408. New Delhi: Indian Council of Historic Research \& Manohar.

Meadow, R. H. and Patel, A. K. (2003) 'Prehistoric pastoralism in northwestern South Asia from the Neolithic through the Harappan period', in Weber, S. A. and Belcher, W. R. (eds) Indus Ethnobiology: New Perspectives from the Field, pp. 65-93. Lanham: Lexington Books.

Meadows, J. R. S., Hiendleder, S., and Kijas, J. W. (2011) 'Haplogroup relationships between domestic and wild sheep resolved using a mitogenome panel', Heredity, 106, 700-6.

Meadows, J. R. S. and Kijas, J. W. (2009) 'Re-sequencing regions of ovine Y chromosome in domestic and wild sheep reveals novel paternal haplotypes', Animal Genetics, 40, 119-23.

Menon, V. (2009) Mammals of India, Princeton: Princeton University Press.

Mishra, B. P., Kataria, R. S., Bulandi, S. S., Prakash, B., Kathiravan, P., Mukesh, M., and Sadana, D. K. (2009) 'Riverine status and genetic structure of Chilika buffalo of eastern India as inferred from cytogenetic and molecular marker-based analysis', Journal of Animal Breeding and Genetics, 126, 69-79.

Mishra, B. P., Dubey, P. K., Prakash, B., Kathiravan, P., Goyal, S., Sadana, D. K., Das, G. C., Goswami, R. N., Bhasin, V., Joshi, B. K., and Kataria, R. S. (2015) 'Genetic analysis of river, swamp and hybrid buffaloes of north-east India throw new light on phylogeography of water buffalo (Bubalus bubalis)', Journal of Animal Breeding and Genetics, DOI: 10.1111/ jbg.12141. 
Misra, V. N. (1973) 'Bagor, a Late Mesolithic settlement in north-west India', World Archaeology, 5, 92-110.

Murray, C., Huerta-Sanchez, E., Casey, F., and Bradley, D. G. (2010) 'Cattle demographic history modeled from autosomal sequence variation', Philosophical Transactions of Royal Society $B, 365,2531-9$.

Nagarajan, M., Nimisha, K., and Kumar, S. (2015) 'Mitochondrial DNA variability of domestic river buffalo (Bubalus bubalis) populations: genetic evidence for domestication of river buffalo in Indian subcontinent', Genome Biology and Evolution, 7(5), 1252-9.

Naderi, S., Rezaei, H.-R., Pompanon, F., Blum, M. G. B., Negrini, R., Naghash, H.-R., Balkız, Ö., Mashkour, M., Gaggiotti, O. E., Ajmone-Marsan, P., Kence, A., Vigne, J.-D., and Taberlet, P. (2008) 'The goat domestication process inferred from large-scale mitochondrial DNA analysis of wild and domestic individuals', Proceedings of the National Academy of Sciences of the United States of America, 105(46), 17659-64.

Nair, P. G., Balakrishnan, M., and Yadav, B. R. (1986) 'The Toda buffaloes of Nilgiri', Buffalo Journal, 2, 169-78.

Patel, A. K. (1997) 'The pastoral economy of Dholavira: a first look at animals and urban life in third millennium Kutch', in Allchin, R. and Allchin, B. (eds) South Asian Archaeology 1995, pp. 101-13. New Delhi: Oxford \& IBH.

Patel, A. K. (2008) 'New radiocarbon determinations from Loteshwar and their implications for understanding Holocene settlement and subsistence in North Gujarat and adjoining areas', in Raven, E. M. (ed.) South Asian Archaeology 1999, pp. 123-34. Groningen: Egbert Forsten.

Patel, A. K. (2009) 'Occupational histories, settlements and subsistence in western India: what bones and genes can tell us about the origins and spread of pastoralism', Anthropozoologica, $44(1), 173-88$.

Patel, A. K. (2015) 'Analysis of faunal remains from excavations at Dholavira (District Kutch, Gujarat)', in Bisht, R. S. (ed.) Excavations at Dholavira 1989-9o to 2004-2005, pp. 839-69. New Delhi: Archaeological Survey of India.

Patel, A. K. and Meadow, R. H. (1998) 'The exploitation of wild and domestic water buffalo in northwestern South Asia, in Buitenhuis, H., Bartosiewicz, L., and Choyke, A. M. (eds) Archaeozoology of the Near East III, pp. 180-99. Groningen: Centre for Archaeological Research and Consultancy, Rijksuniversiteit.

Pérez-Pardal, L., Royo, L. J., Beja-Pereira, A., Chen, S., Cantet, R. J., Traoré, A., Curik, I., Sölkner, J., Bozzi, R., Fernández, I., Alvarez, I., Gutiérrez, J. P., Gómez, E., Ponce de León, F. A., and Goyache, F. (2010) 'Multiple paternal origins of domestic cattle revealed by Yspecific interspersed multilocus microsatellites', Heredity, 105, 511-19.

Possehl, G. L. (1999) Indus Age: The Beginnings, New Delhi: Oxford \& IBH.

Rezaei, H. R., Naderi, S., Chintauan-Marquier, I. C., Taberlet, P., Virk, A. T., Naghash, H. R., Rioux, D., Kaboli, M., and Pompanon, F. (2010) 'Evolution and taxonomy of the wild species of genus Ovis (Mammalia, Artiodactyla, Bovidae)', Molecular Phylogenetics and Evolution, $54,315-26$.

Roberts, T. J. (1997) The Mammals of Pakistan, revised edn, Karachi: Oxford University Press.

Shinde, V. (2008) 'Cultural development from Mesolithic to Chalcolithic in the Mewar region of Rajasthan, India', Pragdhara, 18, 201-13.

Shinde, V., Deshpande, S. S., and Yasuda, Y. (2004) 'Human response of Holocene climatic change: a case study of western India between the 5 th and 3 rd millennia BC', in Yasuda, Y. and 
Shinde, V. (eds) Monsoon and Civilization, pp. 383-406. New Delhi: International Research Center for Japanese Studies \& Roli Books.

Thomas, P. K. (1977) 'Archaeozoological Aspects of Prehistoric Cultures of Western India'. Unpublished PhD dissertation, Deccan College Post-Graduate and Research Institute (Pune).

Thomas, P. K. (2002) 'Investigations into the archaeofauna of Harappan sites in western India', in Settar, S. and Korisettar, R. (eds) Indian Archaeology in Retrospect: Protohistory, Vol. 2, pp. 409-20. New Delhi: Indian Council of Historic Research \& Manohar.

Valdez, R., Nadier, C. F., and Bunch, T. D. (1978) 'Evolution of wild sheep in Iran', Evolution, $32,56-72$.

Yindee, M., Vlamings, B. H., Wajjwalku, W., Techakumphu, M., Lohachit, C., Sirivaidyapong, S., Thitaram, C., Amarasinghe, A. A., Alexander, P. A., Colenbrander, B., and Lenstra, J. A. (2010) 'Y-chromosomal variation confirms independent domestications of swamp and river buffalo', Animal Genetics, 41, 433-5.

Yue, X.-P., Li, R., Xie, W.-M., Xu, P., Chang, T.-C., Liu, L., Cheng, F., Zhang, R.-F., Lan, X.-Y., Chen, H., and Lei, C.-Z. (2013) 'Phylogeography and domestication of Chinese swamp buffalo', PLOS One, 8(2), DOI: 10.1371/journal.pone.0056552.

Zeder, M. A. (2015) 'Core questions in domestication research', Proceedings of the National Academy of Sciences of the United States of America, 112(11), 3191-8.

Zhang, Y., Vankan, D., Zhang, Y., and Barker, J. S. F. (2011) 'Genetic differentiation of water buffalo populations in China, Nepal and south-east Asia: inferences on the region of domestication of the swamp buffalo', Animal Genetics, 42, 366-77. 